\title{
GEOGRAPHICAL ANALYSIS OF THE DISTRIBUTION aNd SPREAd OF Exotic Plant SPECIES IN Grand Teton National Park, Wyoming
}

\author{
DEBORAH KURTZ + RICHARD ASPINALL $\downarrow$ KATHERINE HANSEN \\ DEPARTMENT OF EARTH SCIENCES $\uparrow$ MONTANA STATE UNIVERSITY \\ BOZEMAN
}

\begin{abstract}
$\downarrow \quad$ INTRODUCTION
The effects of introduced exotic species in natural environments are becoming important issues in conservation biology and natural resource management and recent scientific literature reveals increasing concern regarding the spread of invasive exotic plant species (Allen, 1996; Vitousek et al, 1996; Walker and Smith, 1997). Ecological consequences of these species include increased competition for space, water, and nutrients with native plants (which could result in a decrease in biodiversity), decreased forage quality for native ungulates, and changes in the microenvironments where the establishments took place (Woods, 1997). Sheley et al (1998) list several ecologically and economically detrimental impacts of exotic species.
\end{abstract}

The National Park Service recognizes the need to protect ecosystems from exotic species (National Park Service, 1997) through management based on the ability to predict species distributions and spread, and monitoring in areas that are most susceptible to invasion. Recommended strategies for preventing the spread of exotic species include developing an early warning system to identify and eradicate new infestations of exotic plants in National Parks, and continued inventory and monitoring of exotic plants (National Park Service, 1997). These strategies will be based on assessment of the distribution and spread of exotic plants (National
Park Service, 1997) using remote sensing and Geographic Information Systems (GIS) technologies for mapping and monitoring exotic plants, and models to predict the invasiveness and spread of exotic plants.

In Grand Teton National Park (GTNP), exotic species are a great concern for park managers (National Park Service, 1997). Of the 1000 species of flowering plants within GTNP, there are also four (possibly five) rare plants that may be threatened as a result of competition with exotics (Wyoming Rare Plant Technical Committee, 1994): Draba borealis (Boreal draba), Epipactis gigantea (Giant helleborine), Lesquerella carinata var. carinata (Keeled bladderpod), Lesquerella paysonni (Payson's bladderpod), and possibly Draba densifolia var. apiculata (Rockcress draba). The continued survival of these sensitive plants in GTNP increases the need for management of exotic plants.

GTNP has implemented a classification system for exotic plant species that consists of three priority levels (GTNP, 1997a). Priority 1 species are designated as "noxious" since they are capable of invading natural ecosystems and disrupting or displacing native vegetation. Currently, there are thirteen exotic plant species with a Priority 1 status within GTNP (Table 1). 


\begin{tabular}{|ll|}
\hline Table 1. Priority 1 exotic plant species in Grand Teton National \\
Park (Source: Grand Teton National Park, 1997a) \\
\hline \\
Carduus nutans & Musk thistle \\
Centaurea diffusa & Diffuse Knapweed \\
Cirsium arvense & Canada Thistle \\
Centaurea maculosa & Spotted Knapweed \\
Chrysanthemum leucanthemum & Oxeye Daisy \\
Tanacetum vulgare & Common Tansy \\
Verbascum thapsus & Common Mullein \\
Linaria vulgaris & Butter and Eggs \\
Cynoglossum officinale & Houndstongue \\
Hyoscyamus niger & Black Henbane \\
Linaria dalmatica & Dalmation Toadflax \\
Isatis tinctoria & Dyer's Woad \\
Euphorbia esula & Leafy Spurge \\
\end{tabular}

Of the species in Table 1, Canada thistle (Cirsium arvense), Spotted knapweed (Centaurea maculosa) and Musk thistle (Carduus nutans) are of particular importance in GTNP.

\section{$\uparrow$ OBJECTIVE}

The objective of this project is to characterize the distribution and biogeographic controls on exotic plant species within Grand Teton National Park (GTNP). Since the pattern of distribution of a species is related to a variety of environmental characteristics, it is hypothesized that the current distribution of exotic weeds can be characterized based on environmental factors. Furthermore, areas with similar environmental characteristics are expected to be conducive to future occupation by these weeds (Cousens and Mortimer, 1995).

A Geographic Information System (GIS) was used for data management and analysis. It is apparent that a GIS-based model could support and promote the strategies outlined in weed management plans and provide a means for helping to manage exotic plant species in GTNP. The value of GIS for large-scale studies in ecology is increasingly being recognized as researchers are expanding the use of GIS from a simple data storage and mapping tool, to a way of applying statistical and other analytical methods for more rigorous analysis of interdependence and spatial relationships (Burrough and McDonnell, 1998). In this sense, GIS is becoming a significant component of modeling, particularly as ecologists attempt to explain the relationship between vegetation patterns and processes occurring at the landscape scale.
Furthermore, ecologists and vegetation managers are beginning to experiment with these models as a predictive tool.

\section{Study Area}

The study area is located in the southern part of GTNP at the lower elevations of Jackson Hole (Figure 1). This area encompasses 127,028 acres of the front country where the lowest elevations in the park are located and the greatest number of visitors travel. A straight line through the southern portion of Jackson Lake, the middle of Signal Mountain, and just north of the town of Moran determines the northern border.

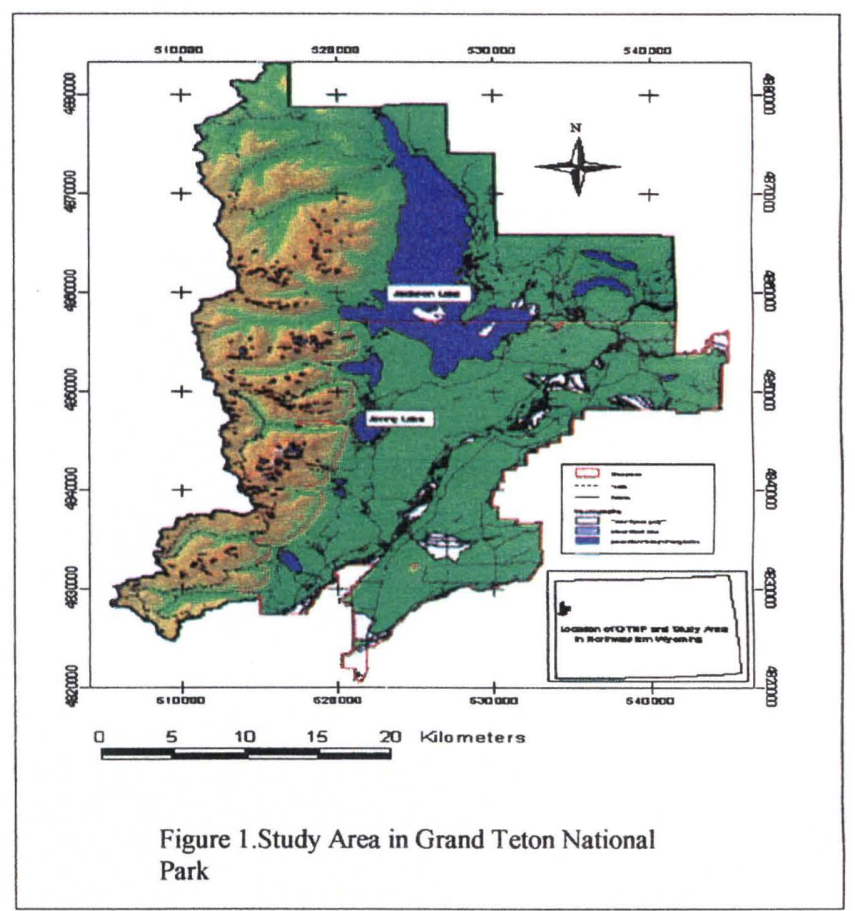

A variety of physiographic features are contained within the study area including the southern end of Jackson Lake, several moraine lakes and other glacial features, the Snake River, the sagebrush flats of the valley, and the lower slopes of the Teton Range. The Tetons are the youngest mountains in the Rocky Mountain chain, forming from an active fault-block where the mountains are being uplifted and the valley of Jackson Hole is being down-dropped (Love and Reed, 1995). The valley floor is dominated by Sagebrush while the Snake River and its tributaries are lined with Willows, Cottonwoods, and Colorado blue spruce (Grand Teton National Park, 1987). 
Data

Geographic and Environmental Data

Geographical data describing the variability in environmental conditions across the study area were derived from maps and other digital databases available at three sites:

i) the GTNP GIS database

ii) the Greater Yellowstone Area Data Clearinghouse (GYADC), and

iii) the United States Geological Survey's Data Clearinghouse

All digital data used from these sources are at a base mapping scale of 1:24000. Eight environmental datasets were integrated into ESRIs ArcView GIS:

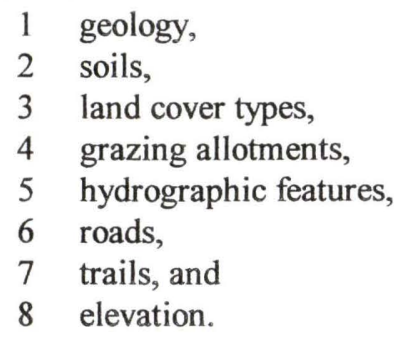

Data for slope and aspect were derived from the elevation layer. Data for temperature and precipitation throughout GTNP are available from previous studies, however, the area of study is sufficiently small and at low elevation that there is not sufficient variability in the precipitation and temperature data to make these data useful for analysis. Elevation, slope, and aspect were created in raster format with $30 \mathrm{~m}$ pixels. All other data were maintained in the database in vector format. All analysis used raster format data with $30 \mathrm{~m}$ pixel size.

Exotic species

Data on exotic species within the study area were from two sources. Data were collected through field work during the summer of 1998, and from records from studies by previous researchers including the annual weed surveys and management teams for the past seven field seasons. This historic dataset was used as a validation dataset.

\section{Sampling Strategy}

Sampling for field work in 1998 was based on a random sample within a framework from the combinations of environmental variables in the GIS database. The sample sites were randomly located based on the pattern of environmental factors. Slope (in 5 degree increments), aspect (in 10 degree intervals), elevation (with 25 meter intervals), distance from roads and trails (in 480 meter increments), soils, and geology were combined in the GIS. Water bodies were excluded. A random sample of the unique combinations was then generated (Figure 2). The locations of these 249 sample sites were calculated with the GIS and a table

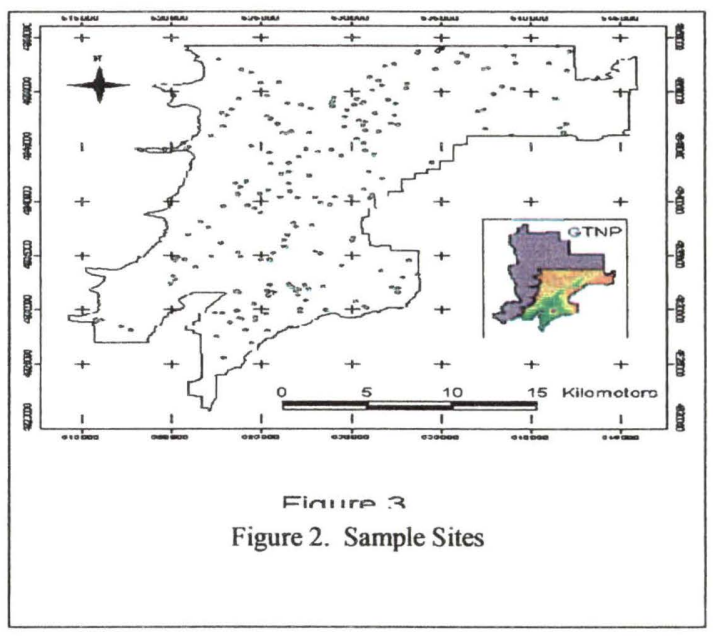

of UTM coordinates and attributes for each site output as hard copy.

Field Sampling

Field sampling was completed between early-July and early-September 1998. Sampling did not begin in June due to cool, wet weather conditions that inhibited plant growth and made identification difficult. Sampling began at the southern end of the study area and progresses northward.

Sample sites were located in the field by their UTM coordinate with the use of $1: 24,000$ topographic maps, a compass, and a Garmin GPS 12 global positioning system. At each site a $30 \mathrm{~m} \times 30 \mathrm{~m}$ plot was laid out. Starting at the southwest corner, one tape measure was run to 30 meters north and one tape measure was laid out 30 meters east to delineate two sides and three corners of the plot. After walking through the plot in a systematic zig$\mathrm{zag}$, data were recorded. Recorded data consisted of:

1 a general description of the location

2 vegetation type and/or dominant plants in 
the plot

3 the presence or absence of each of the thirteen Priority 1 exotics with the percent cover and growth stage of each species present.

Data collection methods were based on Mapping Noxious Weeds in Montana published by the Department of Plant, Soil, and Environmental Sciences at Montana State University. The methodology consisted of cover estimates based on the percent of the ground covered by a particular weed species presented as 1 of 4 cover classes broken down into Trace ( $<1 \%$ cover), Low ( $1-5 \%$ cover), Moderate (5-25\% cover), and High (25-100\% cover). Growth stage classifications were also based on Cooksey and Sheley (1998) and consist of Seedling, Bolt, Bud, Flower, Seed Set, and Mature.

\section{$\downarrow \quad$ ANALYSIS METHODS}

A wide variety of methods have been used for modeling the distribution of plants and animals (Aspinall, 1999). Franklin (1995) reviews many of these methods, particularly as. they use remote sensing and are applied to vegetation. Methods include statistical methods (Noest, 1994; Homer, 1993; Lindenmayer et al, 1991; Austin et al, 1990) and methods based in standard GIS overlay (Hershey et al, 1997; Sperduto and Congalton, 1996; Breininger et al, 1991; Chicoine et al ,1985).

Distribution modeling with Bayes' theorem is used in various studies (Aspinall, 1992, 1994; Aspinall and Veitch, 1993; Pereira and Itami (1991) and offers a number of advantages for this project:

1 continuous (eg elevation, slope) and categorically (eg soil, geology) measured data can be synthesized in one analysis

2 numerous datasets can be incorporated into the model

3 the inductive nature of the method incorporates objectivity

4 the method can be implemented in GIS with relative ease

5 associations between dependent and independent variables can be quantified statistically within a single analytical and data management environment

6 it is based conditional probabilities that provide data on the relationships in the data and are relatively easy to interpret.

$$
\text { Bayesian statistical inference is a }
$$

mathematical method for decision making under conditions of uncertainty and provides a framework for combining relative values of being right or wrong (subjective probabilities) with the probabilities of being right or wrong (conditional probabilities). The modelling approach is based on calculating conditional probabilities from the relative frequency of association between attributes of a dataset to be modelled (for example, the presence and absence of a species at given locations in a landscape) and attributes of a variety of predictor datasets (for example environmental data). Predictor datasets are then combined using Bayes theorem.

The modeling procedure is carried out in a series of stages:

1 Select a series of spatial datasets that contain information that is likely to be related to the distribution in the target (dependent) dataset. The choice of predictors will usually be guided by a conceptual model of environmental or other factors that are thought to influence the distribution to be modelled.

2 Two classes (presence and absence at a site) are identified in the distribution to be modelled.

3 The frequency of association between each attribute, value or category in a predictor dataset is calculated for each class in the target distribution. These frequencies are the conditional probabilities for discriminating presence and absence. Specifically, the conditional probabilities are calculated from the area of overlap between the categories in the target distribution and each of the classes in the predictor dataset.

4 Conditional probabilities for presence are calculated as the proportion of the total area of presence in each class of the predictor dataset. The conditional probabilities for absence are the proportion of the total area of absence in each class of the predictor dataset.

5 The significance of each predictor dataset for discriminating between classes is tested through analysis of frequencies using the Chi square test. A significance level of $95 \%$ was used to set limits on the datasets that were to be included in the Bayesian model of distribution.

6 A priori probabilities for each of the categories are selected. If an initial assumption of equal probability of presence/absence is made the $a$ priori probabilities are set equal at 0.5 .

7 Predictor datasets are combined using the conditional probabilities within Bayes' theorem. The equation for the Bayesian calculation is 


$$
p_{p}=\frac{p p \cdot \prod_{i=1}^{n} c p_{i}}{p p \cdot \prod_{i=1}^{n} c p_{i}+p a \cdot \prod_{i=1}^{n} c a_{i}}
$$

where

$p_{p}$ is the Bayesian probability for presence $p p$ is the prior probability for presence

$p a$ is the prior probability for absence/random

$\prod_{i=1}^{n} c p_{i}$ is the product of conditional probabilities for presence for the attributes in the $\mathbf{n}$ predictor datasets overlaid at a given location in the GIS

$\prod_{i=1}^{n} c a_{i}$ is the product of conditional probabilities for absence/random for the attributes in the $\mathrm{n}$ predictor datasets overlaid at a given location in the GIS.

\section{RESULTS}

Two hundred and two sample sites were visited in 1998. Of the thirteen exotic species recorded, only five species were found in any of the study sites, and these were found in a very low number of sites. Musk thistle was found most frequently ( $16 \%$ of study sites) followed by Canada thistle ( $7 \%$ of the study sites). The three other exotics that were present in any of the study sites were Houndstongue (3 sites), Spotted knapweed (1 site) and Common mullein (1 site). This is a very low incidence of weeds. Musk thistle and Canada thistle were considered to have sufficient data to model their distributions.

Chi square tests of association between the patterns of distribution for Musk thistle and Canada thistle with environmental factors in the GIS show that five environmental factors have a significant association with Musk thistle (Table 2) and four factors have a significant association with Canada thistle (Table 3). Elevation, geology, soil, grazing allotments, and distance from hydrography were associated with Musk thistle distributions. Geology, soil, grazing allotments, and distance from roads were associated with Canada thistle distributions.
Table 2: Results of the Chi square tests of association for Musk thistle

\begin{tabular}{|l|rrrl}
\hline $\begin{array}{l}\text { Environmental } \\
\text { Factor }\end{array}$ & $\begin{array}{c}\text { Chi } \\
\text { Square } \\
\text { Value }\end{array}$ & $\begin{array}{c}\text { Degrees } \\
\text { of } \\
\text { Freedom }\end{array}$ & $\begin{array}{c}\text { Critical } \\
\text { Value }\end{array}$ & $\begin{array}{c}\text { Statistical } \\
\text { Significance } \\
(95 \%)\end{array}$ \\
\hline Elevation & 30.084 & 15 & 24.990 & Significant \\
Slope & 4.707 & 7 & 14.060 & Not significant \\
Aspect & 40.176 & 35 & 48.800 & Not significant \\
$\begin{array}{l}\text { Geology } \\
\text { Habitat Cover }\end{array}$ & 39.965 & 24 & 36.410 & Significant \\
Soil & 7.847 & 7 & 14.067 & Not significant \\
$\begin{array}{l}\text { Grazing } \\
\text { Allotments }\end{array}$ & $\mathbf{5 1 . 9 7 4}$ & 31 & 44.985 & Significant \\
$\begin{array}{l}\text { Distance from } \\
\text { Roads }\end{array}$ & $\mathbf{2 0 . 9 0 6}$ & 1 & 3.842 & Significant \\
$\begin{array}{l}\text { Distance from } \\
\text { Trails }\end{array}$ & 10.968 & 6 & 12.592 & Not significant \\
$\begin{array}{l}\text { Distance from } \\
\text { Hydrography }\end{array}$ & 14.520 & 4 & 9.488 & Significant \\
\hline
\end{tabular}

Table 3: Results of the Chi square tests of association for Canada thistle

\begin{tabular}{l|rrrl}
\hline $\begin{array}{l}\text { Environmental } \\
\text { Factor }\end{array}$ & $\begin{array}{c}\text { Chi } \\
\text { Square } \\
\text { Value }\end{array}$ & $\begin{array}{c}\text { Degrees } \\
\text { Freedom }\end{array}$ & $\begin{array}{c}\text { Critical } \\
\text { Value }\end{array}$ & $\begin{array}{c}\text { Statistical } \\
\text { Significance (95\%) }\end{array}$ \\
\hline Elevation & 18.012 & 15 & 24.996 & Not significant \\
Slope & 4.017 & 7 & 14.067 & Not significant \\
Aspect & 30.468 & 35 & 49.802 & Not significant \\
Geology & $\mathbf{4 0 . 4 7 9}$ & 24 & 36.415 & Significant \\
Habitat Cover & 8.320 & 7 & 14.067 & Not significant \\
Soil & 93.651 & 31 & $\mathbf{4 4 . 9 8 5}$ & Significant \\
Grazing Allotments & $\mathbf{7 . 0 9 3}$ & 1 & 3.842 & Significant \\
Distance from & 23.773 & 6 & $\mathbf{1 2 . 5 9 2}$ & Significant \\
Roads & & & & \\
Distance from Trails & 7.128 & 6 & 12.592 & Not significant \\
Distance from & 7.108 & 4 & 9.488 & Not significant \\
Hydrography & & & & \\
\hline
\end{tabular}

Conditional Probabilities

The conditional probabilities reveal patterns of presence or absence on particular classes for each of the environmental factors. Musk thistle was found to have the greatest number of samples in which it was present in the $1976-2000$ m elevation interval. The greatest percent of no record (absence) of Musk thistle occurred in elevation intervals ranging from $2026-2100 \mathrm{~m}$. The two geologic types with the greatest frequency of Musk thistle were Alluvial Fan Deposits and Alluvial, Gravel, and Sand and Floodplain Deposits. The highest frequency of Musk thistle was on Tineman Gravelly Loam soils. The Taglake-Sebud Association and the Leavitt-Youga Complex soils on 0-3\% slopes had the 
second and third highest frequencies of Musk thistle respectively. Although the majority of sites sampled were relatively near water, the number of sites where Musk thistle was present were near water, especially in the $0-480 \mathrm{~m}$ range.

Canada thistle was only found on six of the twenty-four geologic types sampled. The two geologic types with the frequency of Canada thistle were Alluvium, Gravel, and Sand and Floodplain Deposits and Alluvial Fan Deposits. Canada thistle was also present on Debris of the Jackson Lake Moraine and Swamp Deposits. Among soil types Canada thistle had the highest frequency of presence on the Taglake-Sebud Association and the SlocumSilas Loams. Conditional probabilities for distance from roads revealed that Canada thistle was found most frequently near roads.

Bayesian Models

Bayesian probability models were created from the datasets with significant associations for Musk thistle and Canada thistle. These are shown as maps of the probability of suitable habitat for Musk thistle (Figure 3) and Canada thistle (Figure 4).

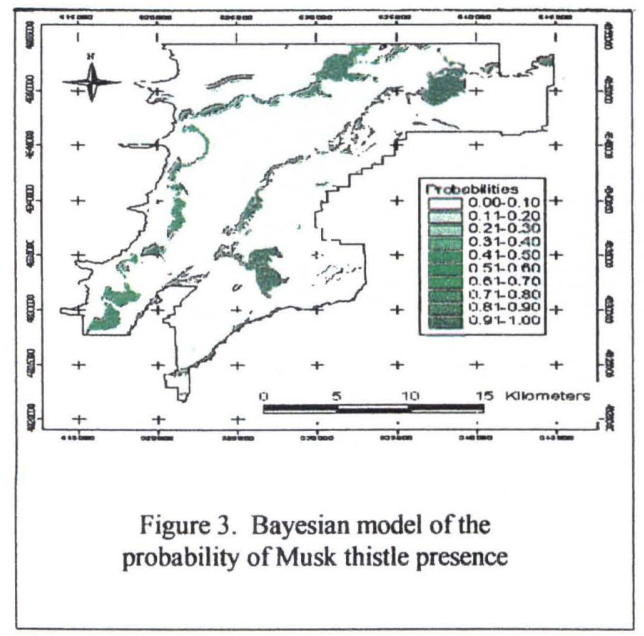

The Musk thistle map identifies areas with the greatest probabilities south and east of Blacktail Butte, west of the town of Kelly and both north and south of Antelope Flats Road. High probabilities (indicating suitable habitat) are also found along the Snake River as a corridor, but not within the meanders, braids, and islands of the river. The shores of Phelps, Taggart, Bradley, and Leigh lakes are all high probability areas, while the portion of Jackson Lake's shore that is in the study area is moderately high. The area aroundthe southern part of Signal Mountain and west-southwest of Uhl Hill are also high probability areas indicating suitable habitat for Musk thistle.

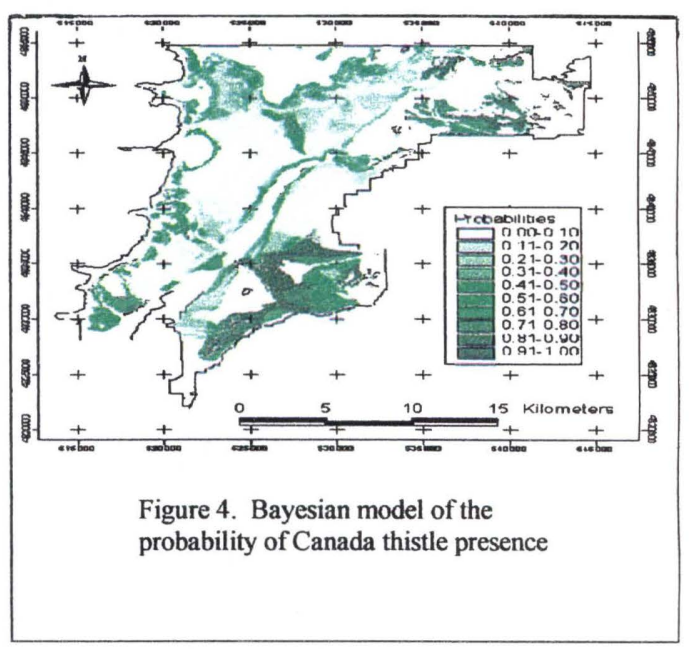

The Canada thistle map has larger areas with high probability values indicating suitable habitat. High probability areas for Canada thistle are within the braids and meanders of the Snake and Gros Ventre river floodplains. The Valley Trail, shores of the moraine lakes, and the southern shores of Jackson Lake are areas that have a high probability. Other suitable areas are east and northeast of Blacktail Butte, Moran Junction, and the west side of Signal Mountain.

\section{Model Validation Results}

Cross-tabulation of GTNP's data for Canada thistle and Musk thistle with the results from Bayes' model reveal a $59.8 \%$ overall accuracy for the Canada thistle model and a $58.5 \%$ overall accuracy for the Musk thistle model. This validation focusses along the roads and trails since these are the areas in which the validation datasets were collected. A probability of 0.70 or higher was arbitrarily chosen to differentiate between suitable and unsuitable habitat for this test. 


\section{$\uparrow \quad$ DISCUSSION}

The objectives of this study were to characterize the distribution of exotic plants in Grand Teton National Park based on environmental factors and to determine other areas in the park suitable for weed infestations. Models have been constructed for Canada and Musk thistle. Other researchers interested in exotic plants have looked at them in terms of roads (Weaver and Woods, 1986; Meier, 1997) and campgrounds (Allen, 1996; Milner, 1995), but have not studied exotics across a given area away from these disturbance sites. A methodological goal of this study was to survey the study area for exotics using a statistically valid sampling strategy. The low frequency of sites at which any exotics were found suggests that exotics are more rare in GTNP than a survey along roads and trails indicates.

Biogeographic environments of Canada thistle and Musk thistle

Results of this study indicate that particular environmental factors are associated with the distributions of Canada thistle and Musk thistle, and that those factors can be used to create preliminary models of the suitability of a site to support a population of Canada thistle or Musk thistle. These results only identify suitable habitats and do not take into consideration life history characteristics, dispersal mechanisms, or impacts of weed control efforts in determination of possible sites for future invasion by exotics. It has also been hypothesized that natural disturbances are an important factor in determining suitable habitat for weeds; incorporating this information would enhance the utility of the models. Attention should also be given to the scale at which weeds respond to environmental (and management) factors. This study has a minimum resolution of $30 \mathrm{~m}$ for environmental data and analysis.

Distance from hydrography had a significant association with Musk thistle. It was surprising that there was not a similar correlation with Canada thistle, although the map produced from Bayesian model shows the banks of the rivers as areas of high probability for presence of Canada thistle. Previous studies have shown Canada thistle to be associated with and/or transported by waterways (Bruns and Rasmussen, 1953).
Musk thistle distribution was also associated with elevation. The geographic pattern of variation in many edaphic and climatic factors is frequently described by the geographic variation in physiographic factors, particularly elevation, aspect, and slope. For example, solar radiation, precipitation, and temperature (Huggett, 1995), which are known to create microclimates that could impact vegetation have strong elevation gradients (Glick et al, 1991). Elevation has been shown to be an important abiotic factor for plant distribution (Bian and Walsh, 1993) and has been proven elsewhere to be a significant environmental factor for Canada thistle (Allen, 1996) and Spotted knapweed (Marcus et al, 1998).

\section{Recommendations for Grand Teton National Park}

Based on the results of this study, it is suggested that GTNP continue their efforts in mapping, preventing, controlling, and eradicating exotic species. Attention should be given to all areas throughout the Park, not just to roadsides and trailsides as exotic species have dispersed beyond these features. Caution should be taken that the focus is not only on more easily controlled species as this may eventually result in the Park becoming overgrown with exotics that are more resistant to control (Westman, 1990). As exotic plant species are removed, erosion control methods should be applied and efforts should be taken to encourage restoration of native plant species. The probability maps produced in this study may aid managers by directing them to monitor areas with high probabilities of suitable habitat for Canada thistle and Musk thistle.

\section{$\uparrow \quad$ CONCLUSIONS}

Exotic species were surveyed at 202 sites in the summer of 1998. The incidence of exotics at these sites was very low. Canada thistle and musk thistle distributions in GTNP were characterized based on associations with environmental variables and maps were created showing the probability of occurrence for these two species throughout the study area. Chi square test results determined elevation, geology, soil, grazing allotments, and distance from hydrography as having significant associations with the distribution of Musk thistle. Chi square tests indicate geology, soil, grazing allotments, and distance from roads as having 
significant associations with the distribution of Canada thistle.

\section{ACKNOWLEDGEMENTS}

This research was supported by the University of Wyoming National Park Service Research Center and the Montana GIS Users Conference GIS Scholarship.

\section{$\downarrow \quad$ Literature CiTED}

Allen, K. 1996. The Distribution of Exotic Plants Adjacent to Campgrounds in Yellowstone National Park, USA. Master's Thesis. Montana State University. Bozeman, Montana.

Aspinall, R. J. and N. Veitch. 1993. Habitat mapping from satellite imagery and wildlife survey data using a Bayesian modeling procedure in GIS. Photogrammetric Engineering and Remote Sensing 59: 537543.

Aspinall, R. J.. 1992. An inductive modeling procedure based on Bayes' theorem for analysis of pattern in spatial data. International Journal of Geographical Information Systems, 6: 105-121.

Aspinall, R J. 1994. Exploratory spatial analysis in GIS: Generating geographical hypotheses from spatial data: In Innovations in GIS 1. Worboys, M., ed. Taylor-Francis.

Aspinall, R. J. 1999 GIS and Landscape Conservation. In: Longley, P., Maguire, D., Goodchild, M., and Rhind, D (eds) GIS: Principles and Applications. Wiley. 2 Volumes. Chapter 69.

Austin, M.P., A.O. Nicholls, and C.R. Margules. 1990. Measurement of the realized niche: Environmental niches of five Eucalyptus species. Ecological Monographs, 60: 161177.
Bian, L and S. J. Walsh. 1993. Scale dependencies of vegetation and topography in a mountainous environment of Montana. Professional Geographer, 45: 1-11.

Breininger, D. R., M. J. Provancha, and R. B. Smith. 1991. Mapping Florida Scrub Jay habitat for purposes of land-use management. Photogrammetric Engineering \& Remote Sensing, 57: 1467-1474.

Bruns, V.F. and L.W. Rasmussen. 1953. The effects of freshwater storage on the germination of certain weed seeds. I. White top, Russian knapweed, Canada thistle, morning glory, and poverty weed. Weeds, 2: 138-147.

Burrough, P. A. and R. A. McDonnell. 1998. Principles of Geographical Information Systems. Oxford University Press. Oxford.

Chicoine, T. K., P. K. Fay, and G. A.Nielsen. 1985. Predicting weed migration from soil and climate maps. Weed Science, 34: 57-61.

Cooksey, D. and R. Sheley. 1998. Mapping Noxious Weeds in Montana. Department of Plant, Soil and Environmental Sciences, Montana State University. Bozeman, Montana 59717.

Cousens, R. and M. Mortimer.1995. Dynamics of Weed Populations. Cambridge University Press, Great Britian.

Franklin, J. 1995. Predictive vegetation mapping: geographic modeling of biospatial patterns in relation to environmental gradients. Progress in Physical Geography, 19: 474499.

Glick, D., M. Carr, and B. Harting. 1991. An Environmental Profile of the Greater Yellowstone Ecosystem. The Greater Yellowstone Coalition. Bozeman, Montana 59771.

Grand Teton National Park. 1997a. Invasive Plant Management Plan. Draft Copy. Office of Science and Resource Management. Moose, Wyoming. 
Grand Teton National Park. 1997b. Annual Report for the Non-Native Plant Management Program in Grand Teton National Park. Office of Science and Resource Management. Grand Teton National Park. Moose, WY 83012.

Grand Teton National Park. 1987. Land Protection Plan. Biennial Review. Moose, Wyoming.

Hershey, B. R., M. A. Ramirez, and D. A. Drake. 1997. Using geostatistical techniques to map the distribution of tree species from ground inventory data, In: Gregoire, T. et al, eds. Modelling Longitudinal and Spatially Correlated Data: Methods, Applications and Future Directions. Lecture Notes in Statistics. Vol. 122. Springer-Verlag.

Homer, C. G., T. C. Edwards, R. D. Ramsey, and K. P. Price. 1993. Use of remote sensing methods in modeling sage grouse winter habitat. Journal of Wildlife Management, 57: 78-84.

Huggett, R. J. 1995. Geoecology: An Evolutionary Approach. Routledge, London.

Lindenmayer, D.B., H.A. Nix, J.P. McMahon, M.F. Hutchinson, and M.T. Tanton. 1991. The conservation of Leadbeater's possum, Gymnobelideus leadbeateri (McCoy): A case study of the use of bioclimatic modeling. Journal of Biogeography, 18:

371-383.

Love, J.D. and J. C. Reed, Jr. 1995. Creation of the Teton Landscape. Grand Teton National History Association. Moose, Wyoming 83012.

Marcus, W. A., G. Milner, and B. Maxwell. 1998. Spotted knapweed distribution in stock camps and trails of the Selway-Bitterroot Wilderness. Great Basin Naturalist, 58: 156-166.

Meier, G. A.. 1997. The Colonization of Montana Roadsides by Native and Exotic Plants. Master's These. Department of Biological Sciences. Montana State University. Bozeman, MT 59717.
Milner, G. M. 1995. The Relationships Between Disturbances in Stock Camps and the Occurrence of Spotted Knapweed (Centaurea maculosa) in the SelwayBitterroot Wilderness in Montana and Idaho. Master's Thesis. Department of Earth Sciences, Montana State University. Bozeman, MT 59717.

National Park Service. 1997. Preserving Our Natural Heritage- A Strategic Plan for Managing Invasive Nonnative Plants on National Park SystemLands.

http://www. naturc.nps.gov/natnct/ww/strat pl.htm

Noest, V. 1994. A hydrology-vegetation interaction model for predicting the occurrence of plant species in dune slacks. Journal of Environmental Management, 40: 119-128.

Pereira, J. M. and R. M. Itami. 1991. GIS-Based habitat modeling using logistic multiple regression: A study of the Mt. Graham red squirrel. Photogrammetric Engineering \& Remote Sensing, 57: 1475-1486.

Sheley, R. L., B. E. Olson, and C. Hoopes. 1998. What is so Dangerous about the Impacts of Noxious Weeds? EB\#152. Montana State University Extension Service.

Sperduto, M. R. and R. G. Congalton. 1996. Predicting rare orchid (small whorled Pogonia) habitat using GIS. Photogrammetric Engineering \& Remote Sensing, 62: 1269-1279.

Vitousek, Peter M., Carla M. D'Antonio, Lloyd L. Loope, and Randy Westbrooks. 1996. Biological invasions as global environmental change. American Scientist 84: 468-478.

Walker, Lawrence R. and Stanley D. Smith. 1997. Impacts of invasive plants on community and ecosystem properties In: James $\mathrm{O}$. Luken and John W. Thieret (eds.). Assessment and Management of Plant Invasions. Springer, New York. 
Weaver, T. and B. Woods. 1986. Roadside Distribution of Exotic Plants in Grand Teton National Park. MSU Biology Report \#39. Bozeman, MT 59717.

Westman, W. E. 1990. Park management of exotic plant species: Problems and issues. Conservation Biology, 4: 251-260.

Woods, Kerry D. 1997. Community response to plant invasion. In: James $O$. Luken and John W. Thieret (eds.). Assessment and Management of Plant Invasions. Springer, New York.
Wyoming Rare Plant Technical Committee. 1994. Wyoming Rare Plant Field Guide. United States Department of the Interior. Bureau of Land Management. 